\title{
IMPLEMENTATION OF THE WORLD HEALTH ORGANIZATION WESTERN PACIFIC REGIONAL PLAN OF ACTION FOR MEASLES ELIMINATION
}

\author{
A.Yu. Antipova, M.A. Bichurina, I.N. Lavrentieva \\ St. Petersburg Pasteur Institute, St. Petersburg, Russian Federation
}

\begin{abstract}
The Western Pacific Region (WPR) is comprised of 37 countries such as China, Japan, Mongolia, Republic of Korea, The Socialist Republic of Vietnam, Papua-New Guinea, Australia, including Pacific Island Countries and Territories (21 countries of PICTs, approx. 3 million people) etc., with a population of 1.85 billion people. Among them, China is the largest and most populous (1.3 billion people) country of the Region. Large measles outbreaks were documented to occur in the Region. In 2003, the Regional Committee announced officially about the WPR action plan on measles elimination 2005, which, however, failed. Since 2012, WPR countries joined the WHO 2012-2020 Global Measles and Rubella Strategic Plan performing a routine measles vaccination (national immunization schedule) or within Expanded Programme on Immunization (EPI). Basically, a two-dose immunization strategy is followed in the WPR countries. Since 2002, measles supplementary immunization activities (SIAs) in children were conducted in the following countries: Japan, Laos, Vietnam, Philippines, Mongolia, Cambodia, Papua New Guinea, and China. Starting from 2005, measles management was considerably improved, demonstrating by 2012 decreased measles incidence rate down to 5.9 cases per million population. In last years, a decreased measles immunization coverage in decreed population groups was noted in the WPR countries that resulted in 2013-2015 measles epidemic involving almost all regional countries. In particular, in China measles incidence rate was 19.6 cases per million population, whereas in the Vietnam Papua New Guinea and Philippines it progressively increased reaching $182.8,345.9$ and 548.0 cases per million population, respectively. Early children not vaccinated according to schedule, adolescents and young adults dominated among measles patients. It was found that measles outbreaks were due to missed vaccination and increased level of vulnerability to measles. Children under one, adolescents and young adults who did not receive a two-dose measles vaccination were in risk group. Analyzing WPR measles epidemiology demonstrated that refusal of parents to vaccinate children, poor knowledge of advantages related to vaccination, insufficient immunization coverage in immigrants, travelers, subjects changing place of residence, workers of healthcare and educational facilities require special attention. In 2017-2018 season, the following measles genotypes were found in the WPR: D8 - Australia, New Zealand, Republic of Korea, Singapore, Japan; H1 - China; B3 - Philippines, Australia and Japan; D9 - Singapore, Australia, Macau (China), Malaysia and Japan, H2 strains endemic in Vietnam. According to the WHO, measles endemic transmission has been successfully interrupted; Australia, Macau, Mongolia and Republic of Korea are being verified to eliminate measles; Hong Kong (China) and Singapore (based on available information) are ready to verify measles elimination. Thus, in the Western Pacific Region measles elimination is achievable after solving current issues such as increasing and maintaining high-level routine vaccination and conducting measles supplementary immunization campaigns in epidemically important contact clusters.
\end{abstract}

Key words: measles, Western Pacific region, disease incidence, elimination program, vaccination schedule, genotype.

\section{Адрес для переписки:}

Антипова Анастасия Юрьевна

197101, Россия, Санкт-Петербург, ул. Мира, 14,

ФБУН НИИ эпидемиологии и микробиологии имени Пастера.

Тел.: 8 (812) 232-94-11 (служебн.).

Факс: 8 (812) 233-20-92.

E-mail: anti130403@mail.ru

\section{Библиографическое описание:}

Антипова А.Ю., Бичурина М.А., Лаврентьева И.Н. К вопросу

о реализации программы элиминации кори в странах Западно-

Тихоокеанского региона В03 // Инфекция и иммунитет. 2018. Т. 8, № 4

C. 465-472. doi: 10.15789/2220-7619-2018-4-465-472

\author{
Contacts: \\ Anastasiya Yu. Antipova \\ 197101, Russian Federation, St. Petersburg, Mira str., 14, \\ St. Petersburg Pasteur Institute. \\ Phone: +7 (812) 232-94-11 (office). \\ Fax: +7 (812) 233-20-92. \\ E-mail: anti130403@mail.ru
}

\section{Citation:}

Antipova A.Yu., Bichurina M.A., Lavrentieva I.N. Implementation of the World Health Organization Western Pacific regional plan of action for measles elimination // Russian Journal of Infection and Immunity = Infektsiya i immunitet, 2018, vol. 8, no. 4, pp. 465-472. doi: 10.15789/2220-7619-20184-465-472 


\title{
К ВОПРОСУ О РЕАЛИЗАЦИИ ПРОГРАММЫ ЭЛИМИНАЦИИ КОРИ В СТРАНАХ ЗАПАДНО-ТИХООКЕАНСКОГО РЕГИОНА ВОЗ
}

\author{
Антипова А.Ю., Бичурина М.А., Лаврентьева И.Н. \\ ФБУН НИИ эпидемиологии и микробиологии имени Пастера, Санкт-Петербург, Россия
}

Резюме. Западно-Тихоокеанский регион (ЗТР) объединяет 37 государств, в том числе Китай, Японию, Монголию, Республику Корея, Вьетнам, Папуа-Новую Гвинею, Австралию и др. Из них 21 страна известна как Тихоокеанские Островные государства и территории (ТОГТ). Население Западно-Тихоокеанского региона составляет 1,85 млрд человек. Самой большой страной региона по площади и по численности населения (1,3 млрд человек) является Китай. В странах ТОГТ проживает около 3 млн человек. На островах развивались особенно крупные вспышки кори. В 2003 г. Региональный Комитет формально объявил целью элиминацию кори в ЗТР к 2005 г., однако достичь ее не удалось. С 2012 г. страны ЗТР присоединились к программе элиминации кори ВОЗ и Глобальному плану элиминации кори к 2020 г. Все страны ЗТР проводят вакцинацию против кори в рамках рутинной иммунизации (национальные календари прививок) или программы расширенной иммунизации (ПРИ). В основном в странах региона используется двухдозовая стратегия иммунизации. Программы дополнительной иммунизации (ПДИ) детей против кори, начиная с 2002 г., выполнили ряд государств: Япония, Лаос, Вьетнам, Филиппины, Монголия, Камбоджа, Папуа-Новая Гвинея, Китай. Начиная с 2005 г. ситуация по кори в ЗТР значительно улучшилась, к 2012 г. показатель заболеваемости в целом снизился до 5,9 на 1 млн населения. В последние годы в странах ЗТР наблюдалось снижение уровня охвата вакцинацией декретированных групп населения, и в 2013-2015 гг. в ЗТР распространилась очередная эпидемия кори, в которую в той или иной степени были вовлечены почти все страны региона. В Китае показатель составил 19,6 на 1 млн. Наиболее высокие показатели (на 1 млн заболевших) были отмечены на Филиппинах $(548,0)$, в Папуа-Новой Гвинее $(345,9)$, во Вьетнаме $(182,8)$ и др. Среди заболевших преобладали не вакцинированные по возрасту дети младшего возраста, а также подростки и молодые взрослые. Вспышки кори были связаны с наличием «пропусков» иммунизации и увеличением количества восприимчивых к кори лиц. В группе риска дети до года, подростки и молодые взрослые, которые не получили 2 дозы вакцины. Анализ эпидемической ситуации в регионе показывает, что требуют решения проблемы отказа родителей от вакцинации детей, неосведомленность населения о преимуществах вакцинации; недостаточный уровень охвата иммунизацией мигрантов, путешественников и лиц, меняющих место жительства, работников медицинских и образовательных учреждений. В 2017-2018 гг. в регионе определялись генотипы: D8 - Австралия, Новая Зеландия, Республика Корея, Сингапур, Япония; Н1 - Китай; B3 - Филиппины, Австралия и Япония; D9 - Сингапур, Австралия, Макао (Китай), Малайзия и Япония. Штаммы генотипа Н2 эндемичны для Вьетнама. По данным ВО3 в Бруней-Даруссаламе, Камбодже и Японии эндемичная трансмиссия кори прекращена; Австралия, Макао, Монголия и Республика Корея находятся на этапе верификации элиминации кори; Гонконг (Китай) и Сингапур (по имеющейся информации) готовы к верификации элиминации кори. Таким образом, элиминация кори в 3ТР ВО3 достижима при решении существующих проблем - повышения и поддержания высокого уровня рутинной вакцинации и проведения кампаний дополнительной иммунизации эпидемически значимых групп населения.

Ключевые слова: корь, Западно-Тихоокеанский регион, заболеваемость, программа элиминации, календарь прививок, генотип.

\section{Introduction}

The strategic plan for measles elimination by 2020 (WHO, 2012) calls for elimination in at least five WHO regions, with the exception of the South-East Asia [1, 2, 3, 23].

The Western Pacific Region (WPR) includes 37 continental and island states. Of these, 21 countries are known as the Pacific Island Countries and Territories (PICTs). PICTs are characterized by active migration of residents between the islands and towards urban centers. Geographical environment differs markedly from that of most other countries, and extreme weather conditions upset regular medical care for many months. Due to these peculiarities, PICTs are united into one group for the epidemiological surveillance of measles [18, 27].

The population of the Western Pacific Region is 1.85 billion people. The largest country in the region, both in terms of area and population, is China
(1.4 billion people). The population of Papua New Guinea is 7 million people. About 3 million people live in PICTs. Other WPR countries include Australia, Vietnam, Mongolia, Republic of Korea, Japan, and others [29].

\section{The measles surveillance system in the countries of the WHO Western Pacific Region}

In the Western Pacific Region, particularly large outbreaks of measles have developed on the islands. In 1875,27 to 50 thousand Fiji residents died as a result of importing the measles virus into a nonimmune population. In 1893, the twentieth of the population of Tonga died [18].

The fight against measles in the WPR began in the second half of the $20^{\text {th }}$ century, but until 2000 the incidence rate remained high. For example, in the 
Marshall Islands measles epidemics occurred every 10 years - in 1968, 1978, and 1988 [18].

In 2003, the Regional Committee formally declared the goal of eliminating measles in the WPR by 2005 (Western Pacific Regional Plan of Action for Measles Elimination). It was not achieved, however. A new goal for the countries of the region has become the elimination of measles by 2012, according to the Regional Strategy and Plan of Action for Measles and Rubella Elimination in the Western Pacific [5, 20, 22]. National plans were developed to achieve this goal. For example, in 2006, the Chinese Ministry of Health developed a plan of action for eliminating measles in 2006-2012. The elimination strategy included immunization, epidemiological surveillance and infection control [8]. This goal was also not achieved by 2012, so the WPR countries joined the WHO Measles Elimination Plan and the Global Measles Strategic Plan purporting the measles elimination by 2020 . A detailed plan of action to achieve the goals was outlined in the Regional Framework for Implementation of the Global Vaccine Action Plan in the Western Pacific [20].

National systems of measles surveillance are currently being improved. In addition to the guidelines of the WHO Regional Office, the WPR states and territories have national regulatory documents governing the activities on the elimination of measles. In China, they have a National Measles Surveillance Guideline (1998, 2003) [8]. Japan has a guideline of the Ministry of Health, Labor and Welfare (Social Security) (Special Infectious Disease Prevention Guidelines for Measles) and the Infectious Diseases Control Law (2008) [11, 13].

The virological surveillance has become an integral part of the surveillance system for measles in all countries of the region. For example, in China a measles laboratory network operates since 2001, including 331 prefecture laboratories in 31 provinces. The National Measles Laboratory of China became the regional reference laboratory in the WPR in 2003 [5]. In the WPR countries (including Japan (since 2008) and China (since 2009)), a system of measles surveillance was launched based on the investigation of each suspected measles case supported by laboratories $[8,13]$. In China, clinical samples for measles diagnosis are sent to measles laboratories, and samples for genotyping are sent to the National Measles Laboratory [8]. In Japan, upon registration of a suspected measles case, a medical institution sends clinical samples to prefecture and municipal health institutions for the isolation and genotyping of the measles virus and to a commercial laboratory for the detection of IgM antibodies to the virus (through national health insurance).

Data representation and analysis systems are being improved. In China, measles is subject to registration since the 1950s. In 2005, the National Disease Reporting System was implemented. Epidemiological data from hospitals and regional Centers for Disease Control and Prevention are transmitted over a computer network to the National Center for Disease Control and Prevention. The mandatory registration of all sus- pected measles cases is carried out in Japan. If the diagnosis is confirmed by a laboratory examination, then a confirmed measles case is recorded. In 2008, only $38 \%$ of suspected measles cases underwent laboratory examination and were confirmed. In 2014, such cases made up $90 \%$, and genotyping was performed in $78 \%$ of cases $[13,26]$. In Vietnam, epidemiological data are collected from four measles laboratories, where the registration forms for investigating measles cases are filled in monthly [14]. These data are then sent to the EPI National Institute of Hygiene and Epidemiology.

\section{Preventive vaccination of measles}

All WPR countries carry out vaccination against measles as part of routine immunization (national vaccination schedules) or the Expanded Program on Immunization (EPI). Investigations into a number of major outbreaks in the region involving people vaccinated against measles have justified a two-dose immunization strategy [10], which has been adopted in almost all countries of the region.

Different vaccination schemes are used. In China, a single dose of measles vaccine to children at the age of 8 months was included in the national vaccination schedule in 1978 [5, 8]. The second dose of the vaccine was recommended in 1986 at the age of 7 years, and in 2005 the age of administration was reduced to 18-24 months. In Japan, routine immunization has been carried out since 2006 using measles- and rubella-containing vaccines at the age of one year (first dose) and before entering school (second dose) [13]. In Australia, the first and the second doses are administered to children aged 12 and 18 months respectively [9]. In Vietnam, vaccination against measles with a single dose was introduced into the routine immunization schedule in 1982. Since 2001, vaccination of children from 9 months to 6 years has been accepted as part of the National Expanded Program on Immunization. Since 2006, scheduled vaccination against measles with first and second doses was introduced for children aged 9-11 months and 18 months respectively [4, 14, 17]. In PICTs, immunization schedules vary considerably. The first dose of measles-containing vaccine is intended for children aged 12-15 months. The age of the second dose varies from 13 months to 6 years. In 2015, 20 PICTs adopted a two-dose vaccination strategy $[10,18]$.

In order to eliminate measles according to WHO recommendations, it is necessary to maintain a vaccine coverage rate of at least $95 \%$. In addition to routine immunization, 7 of the 16 non-island states performed supplementary immunization activities (SIAs) or campaigns against measles. For example, in various parts of Vietnam, SIAs for the population aged between 9 months and 10 years were executed in 2002-2003 and for the population aged between 6 and 20 years - in 2004, 2007 and 2008 [17]. In the Lao People's Democratic Republic, SIAs were performed in 2011 and 2014; in the Philippines, children born in 2002-2010 and 2009-2013 were vaccinated in 2011 
and 2014 respectively. SIAs were also performed in Mongolia (2012), Cambodia (2013), and Papua New Guinea (2015-2016).

In Japan, from 2008 to 2012, a vaccination session was performed for students of the first grade of middle school (13 years old) and the third grade of high school (18 years). Two doses of vaccine were administered to children born in 1990-1999 [13].

An unprecedented SIA session was carried out in China. The coverage rate of the primary measles vaccination in China was not sufficient, although increased from $80.4 \%$ in 2000 to $91.1 \%$ in 2009 . The coverage rate for the booster vaccination in 2009 was $84.3 \%$. In order to stop the spread of measles virus among children under the age of 14 , who were most involved in the epidemic process, 27 out of 31 provinces of China initiated SIAs against measles independently between 2003 and 2009, getting 185.7 million children vaccinated. However, despite the success of individual territories, a new increase in the incidence of measles has been observed since 2008. In September 2010, a national program for supplementary immunization using measles-containing vaccine was performed, which covered the children from decreed groups regardless of their vaccine status. Within three weeks, more than 100 million children were vaccinated; vaccination coverage was $97.5 \%[5,14]$.

In 2014, mass vaccination sessions against measles and rubella were conducted in the Federated States of Micronesia, the Lao People's Democratic Republic, the Philippines, the Solomon Islands and Vietnam.

Thanks to SIAs, the vaccination coverage in the region has increased significantly. For example, in Vietnam in the period between 1994 and 2009, the primary vaccination coverage was $93-97 \%$, with the exception of 2007 (83\%) [17]. In Japan, the first dose vaccination coverage in 2010-2013 was at least $95 \%$ of children, who were subject to routine vaccination. The coverage rate for the second dose in 2013 was $93 \%$.

In 2014 in Japan, when studying the population immunity to measles, it was shown that $73 \%$ of children under 5 months had (maternal) antibodies; at 611 months, $12 \%$ of children were seropositive, and at least $95 \%$ of people in age groups older than 2 years had IgG antibodies to measles virus [13].

Among Australian students, $20.9 \%$ were vaccinated, while $51 \%$ had unknown vaccine status. The risk group contained all people born after 1966, who did not receive two doses of the vaccine.

In recent years, there has been a tendency in the WPR countries to reducing or stagnating coverage of the decreed population groups by vaccination. For example, a study of the intensity of immunity against measles virus in Australia showed that the vaccination coverage rate was $93.3 \%$ in children at the age of five [9]. During the measles outbreak in Vietnam in April 2014, the absolute majority of affected children $(86 \%)$ were not immunized or no vaccination data were available [4].

To achieve the goal of eliminating measles in the WPR countries, it is necessary to have a large number of doses of a thermostable vaccine, as it should be administered in a tropical climate. In close cooperation with Japan (Kitasato Institute, Tokyo), PolyVac vaccine was developed and tested in Vietnam (Military Academy of Medicine, Hanoi) on the basis of AIK-C vaccine strain (Kitasato Institute, Tokyo). This is the first vaccine that was produced in Vietnam by the Center for Research and Production of Vaccines and Biology (Ministry of Health) as part of the project launched in 2013 that included the transfer of POLYVAC technology and was funded by the Japan International Cooperation Agency (JICA). The project aims to create a combined measles and rubella vaccine corresponding to WHO standards. In March 2016, with the assistance of Japanese experts from the Japanese technology transfer unit (Kitasato Daiichi Sankyo Vaccine) and the Center's staff, a clinical trial was carried out for the measles and rubella vaccine, which proved to be safe and effective. With a current capacity of 7.5 million doses per year, the Center can fully meet domestic demand for vaccines and even export them in future. Currently, Vietnam is among the 25 states in the world that can produce vaccines and four Asian states that can produce a measles and rubella vaccine (after Japan, India and China) [24].

\section{The incidence of measles in the WHO Western Pacific Region}

In 1974, at the beginning of the Expanded Program on Immunization, 3381826 cases of measles were registered in the WHO Western Pacific Region, with 33818 children's deaths due to measles. By 1990, vaccination coverage in the region reached 93\%, the number of measles cases was reduced to 155000 and the number of deaths up to $1561[18,20]$. However, the data reported through the WHO/UNICEF joint reporting form (JRF) could be understated due to weak surveillance systems, especially in countries and areas with the greatest burden of diseases. WHO estimates that in 2002 the number of measles cases in the region could reach 6.7 million; measles could be the cause of 30000 deaths. For example, in 2003, a large measles outbreak in the Marshall Islands ended after more than 35000 from 51000 people were vaccinated, despite a reported high enough measles vaccination coverage (80-93\%) before the outbreak [10, 18].

As a result of the implementation of the Regional Strategy and Plan of Action for Measles and Rubella Elimination in the Western Pacific, the situation of measles in the WPR has improved significantly since 2005. From 2009 to 2012, the number of laboratoryconfirmed cases of measles in the WPR decreased by $84 \%$; the incidence rate as a whole decreased to 5.9 per 1 million people. The highest incidence of measles (confirmed cases) was in Malaysia (63.7 per million of population), Philippines (15.9 per million of population), and New Zealand (12.3 per million of population) [16].

However, in 2013-2015, another measles epidemic began in the WPR, which involved all countries of the 
region in varying degrees. In 12 countries, the incidence rate significantly exceeded 10 per 1 million people. The peak incidence in most countries fell in 2014, when 80576 cases of measles were recorded in the region (fig.) [31].

The highest rates were recorded in the Philippines 548.0 per 1 million population (54 669 cases) and Papua New Guinea - 345.9 (2589 cases), and in Vietnam, the rate was 182.8 per 1 million (16 741 cases). In 2014, 834 confirmed cases were registered in Thailand [9]. In the island states (PICTs), 279 cases of measles (85.3 cases per 1 million of population) were recorded, including 257 in the Federated States of Micronesia, where the incidence rate was 2473.5 per 1 million people. In Mongolia in 2015, there were 20374 cases of measles and 28813 cases in 2016 [21, 27].

The Solomon Islands experienced a measles epidemic in June 2014 after the return of travelers from Papua New Guinea with 4654 suspected measles cases, including 38 serologically confirmed [18, 27]. To stop the outbreak on the islands, an additional immunization session was carried out. All residents between the ages of 6 months and 30 years were vaccinated first in the epicenter of the outbreak, then in the remaining territories [18]. Measles was also recorded in New Zealand (274 cases, 60.2 per 1 million of population). In Australia outbreaks were associated with the importation of the virus from other countries [9]. The majority of the diseased was constituted by children who had not been vaccinated according to age, adolescents and young adults .

Note should be made of the situation with measles in the mainland countries of the region. China has the bulk of all cases of measles in the WPR, so a de- crease in the incidence in the region is associated with control over this infection in China. The average annual incidence rate per 100000 of population in 19601969 was 572.0 and 355.3 in 1970-1979 [8]. During 1995-2004, as a result of successful vaccination sessions, the incidence rate dropped to 6 per 100000 population [5]. Despite the successes, large increases in measles incidence were noted in 2003, 2005-2007, 2009, 2011-2012. In total, from 2005 to 2012, there were 569948 measles cases registered in the country (59.9\% among males), including 344 deaths. Children under 1 year and people aged from 15 to 35 were most affected [5, 8]. Nevertheless, the number of registered measles cases was declining steadily, and in 2012 the incidence rate was 4.6 per 1 million of population, with $98.3 \%$ of cases being confirmed in laboratory [16]

However, in 2013, another epidemic increase in the incidence rate was registered in China, when the figure was 19.4 per 1 million of population and 26883 cases of measles were registered. The maximum was noted in 2014 (52 628 cases of measles). Two peaks of incidence were observed, one in April-May and another in August-October. Among the diseased, children prevailed; the average age of the patients was 11 months. Twenty-four deaths were recorded, 13 of them in children less than 8 months old, 8 at the age of $8-23$ months, and 3 cases in children in the $24-48$ month age group. The rise in incidence was due to a decrease in the coverage with primary vaccinations; in the $8-23$ month age group, $72 \%$ of children were not vaccinated in 2013 [5, 8]. In 2016 and 2017 there were 25584 and 5999 confirmed cases of measles in China and the incidence rate was 18.5 and 4.3 per 1 million of population respectively $[24,25]$.

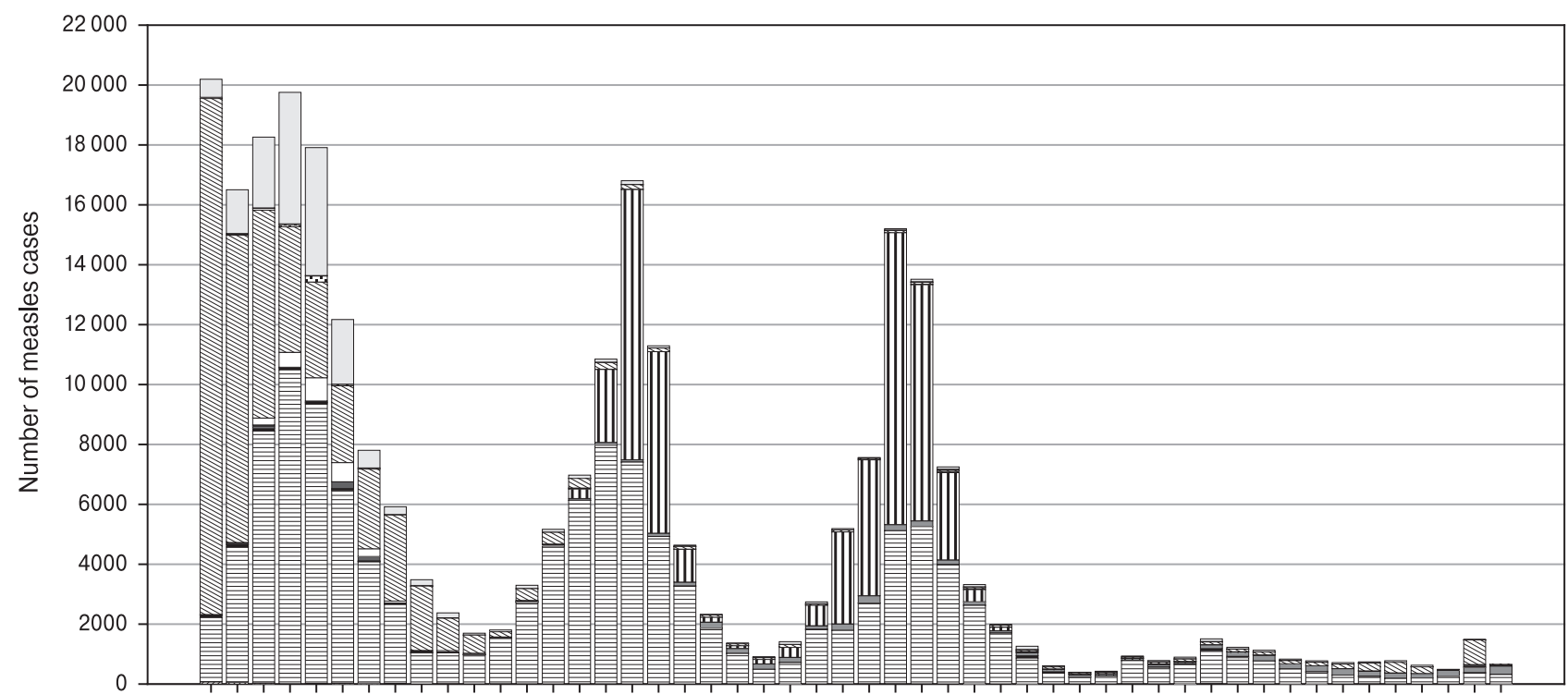

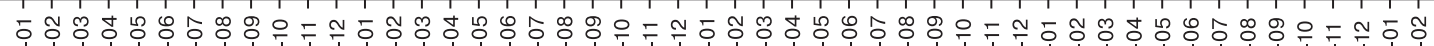

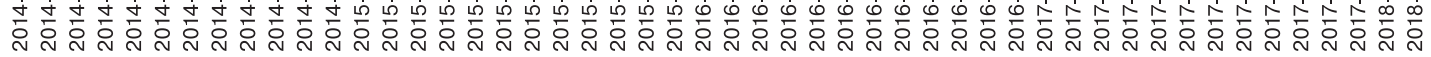
Month of onset

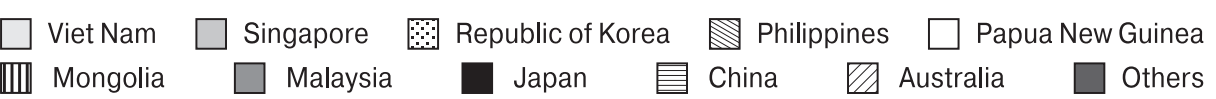

Figure. Measles case distribution (WPR), 2014-2018 
Japan is a measles-free country, despite its large and dense population. However, in 2014, as a result of the importation (from the Philippines, in particular), a measles outbreak began in the country, involving employees of educational institutions and medical personnel. Due to active supervision, the outbreak ended in about one week. Of the diseased, $47 \%$ were not vaccinated, $19 \%$ were vaccinated once, $7 \%$ were vaccinated twice, and $27 \%$ did not know their vaccine status. The proportion of children under the age of 1 year was $20 \%$, of which $83 \%$ were not vaccinated. The share of adults ( $\geq 20$ years) constituted $70 \%$ of measles cases that occurred in 2013, compared to 33\% in 2008. Among the diseased who were older than 6 years and should have received two doses of the vaccine, 70 of 142 (49\%) were not vaccinated [12, 13]. After stopping the outbreak, the incidence rate in Japan was 0.3 per 1 million of population in 2015 [13, 27]. In 2017, 187 confirmed cases were registered, the incidence rate being 1.46 per 1 million of population $[24,25]$.

In Vietnam, the high incidence is also due to the shortcomings of preventive vaccination of measles and to the presence of a large number of people susceptible to measles. From 2004 to early 2008, there were isolated outbreaks of measles in Vietnam, mainly in the mountainous areas of the Northern Region of the country. In October 2008, measles outbreaks were reported in three provinces of the Northern Vietnam. In Vĩnh Phúc province, 17 college students fell ill with measles. In Thanh Hóa province, measles had spread among children under the age of 15 , but the outbreak ended after mopping up immunization in December 2008. The highest number of cases was in Hanoi province. The first rash case was registered on October 20 in a 19-year-old student of one of Hanoi educational institutions. By the end of 2008, 84 confirmed measles cases had been reported, 68 of them among 18-26-year-olds. In total, 184 measles cases were reported in Vietnam in 2008. From October 2008 to January 2010, there were 7948 confirmed measles cases in 60 of the 63 Vietnam provinces, the incidence rate being 93 cases per 1 million of population [17, 30]. High incidence rates were noted in two age groups children under 12 months and at the age of 1-4 years (318 and 328 cases per 1 million of population respectively). Among those who fell ill, 53\% were older than 15 years. These were mainly students of colleges and universities [17]. Only $30 \%$ of patients were vaccinated. The 2013-2015 measles epidemic in Vietnam affected 24 cities and provinces, including major urban centers like Hanoi and Ho Chi Minh City. In 2013, 1233 confirmed measles cases were registered and 7580 in 2014 [4, 30]. In 2014, the coverage rate of the first dose of measles vaccine was $85.6 \%$ [6]. Among those who fell ill in 2014, only $22.4 \%$ of children over 1 year were vaccinated once, $1.3 \%$ were vaccinated twice, and $76.3 \%$ had no information about vaccination [14]. In 2014-2015, an additional immunization session against measles was organized in Vietnam for children born between 2000 and 2013 [20]. In 2016, 368 cases of measles were registered, the incidence rate being 3.9 per 1 million of population; in 2017, 588 cases of measles with an incidence rate of 6.22 per 1 million [25].

The Philippines is one of the countries most heavily afflicted by measles. About 60000 cases of measles were registered between 2011 and 2014, with a peak in 2014 after Typhoon Haiyan [9], the incidence rate being 548 per 1 million. In 2017, there were 1602 cases of measles [24, 25].

The measles outbreak did not stop in Malaysia, where the number of cases increased from 22 in 2014 to 1964 in 2017, the incidence rate being 61.7 per 1 million of population [25, 27].

The criterion for measles elimination is the absence of circulation of endemic measles virus within 36 months from the date of registration of the last case, provided that an adequate system of measles surveillance is in place.

During the 2009-2012, measles viruses of D9 (Philippines, Malaysia and Singapore), D8 (Malaysia) and H1 (China, identified since 1993) genotypes were most frequently detected in the WPR. Until May 2010, measles viruses of D5 genotype circulated in Japan. B3, D4 and G3 genotypes, which were found in the WPR during this period, were imported from other regions [10, 16]. In 2009-2012, measles viruses of D4, D8, D9 and D11 genotypes were also found in China. Since 2003, measles viruses of $\mathrm{H} 1$ and $\mathrm{H} 2$ genotypes have been detected in the central (Nha Trang) and northern (Hanoi) parts of Vietnam [7]. H2 strains are endemic and are circulating constantly in the capital of Vietnam. Viruses of $\mathrm{H} 1$ genotype were detected in 2008-2010 (Northern and Southern Regions) and in 2014 (Hanoi). Both endemic transmission and importation from China are probable [17]. Since 2014, measles viruses of D8 genotype have been isolated in South Vietnam, which have at least three unique amino acid sequences in the $\mathrm{N}$ gene and form a separate D8-VNM cluster. The strain of measles virus from India is probably the closest one to the ancestral form of this genovariant [14, 20, 27]. In 2014-2015, the H1 genotype prevailed in the WPR (China, Mongolia); B3 and D8 were detected, but there was no D9 genotype [31]. In 2017-2018, the following genotypes were identified in the region: D8 in Australia, New Zealand, Republic of Korea, Singapore, Japan; H1 in China; B3 in Philippines, Australia and Japan (including those imported from the Philippines); D9 in Singapore, Australia, Macau (China), Malaysia and Japan [5, 8, 13, 27, 28].

The Regional Verification Commission for Measles Elimination in the Western Pacific Region found in 2015 that endemic transmission of measles virus was stopped in Brunei, Cambodia and Japan. Australia, Macau, New Zealand and the Republic of Korea are at the stage of verifying measles elimination; Hong Kong (China) and Singapore (according to available information) are ready to verify the elimination of measles. New Zealand and the Republic of Korea were also the first to confirm the elimination of rubella in 2015 [9, 21, 22]. In 2015, a measles outbreak began in Mongolia. The majority of confirmed cases were in children under 9 months of age, but there 
were more suspected measles cases in those aged 1524 years; $80 \%$ of the diseased were not vaccinated [31].

Despite the fact that in 2017 the incidence of measles in the region decreased to 11.8 per million of population, the spread of the infection did not stop. In January 2018330 confirmed cases of measles from 708 in the region were registered in the Philippines and 290 cases were registered in China [27]. Measles outbreaks were also registered in Malaysia, Papua New Guinea and Vietnam [9, 21, 22].

\section{Conclusion}

Despite the success of preventive vaccination, measles outbreaks are associated with "skipped" immunizations and an increase in the number of people susceptible to measles. Risk groups are children under one year, adolescents and young adults who have not received two doses of the vaccine. [5, 8]. It is essential that a high level of vaccination coverage is maintained. Special attention should be paid to persons, who were not included in the vaccination programs and were not covered by the second dose of measles-containing vaccine, not to mention the first one.

Parents' refusal to vaccinate children prevents achievement of measles elimination. It is noted that the development of the epidemic of the disease in Vietnam was facilitated by insufficient awareness of parents and loss of public confidence in the government vaccination program $[6,15]$. Many parents stopped vaccinating their children, leaving them susceptible to measles. For many countries in different WHO regions it has been shown that the level of people's awareness of the benefits and risks of vaccination corresponds to the level of education. Governments use different ways of convincing people about the advantages of immunization. For example, in Australia, a "No Jab, No Pay" policy has been introduced, related to financial incentives for parents [9].

The vaccination of travelers and people changing their place of residence is an important part of preventive measles vaccination program. In Australia, the most popular tourist routes include Indonesia (Bali), Thailand, India and China. In 2014-2015 about 9.2 million people traveled abroad. Studies have shown that only $1.6 \%$ of Australian travelers were vaccinated against measles prior to travel. Among the measles cases, $80 \%$ of people have repeatedly traveled outside of Australia [9]. It was also shown that in Australia, migrants are the key risk group to be vaccinated against measles.

In China more than $30 \%$ of measles cases were registered in 2005-2007 among the "floating population", that is, people without a permanent residence permit in the area where they actually lived. Routine vaccination is carried out at the place of official registration. The number of "floating" people is constantly growing due to the increased migration of rural population to urban centers [4]. It is necessary to increase the level of vaccination coverage among travelers.

Timely diagnosis of measles and compliance with the anti-epidemic regime remains a major problem. During a measles outbreak in Hanoi, parents often brought sick children to the hospital, which soon became the source of infection of measles-contact children and the center for transmission of infection $[4,19]$.

To sum up, seven countries in the Western Pacific Region achieved measles elimination by 2017: Australia, Brunei, Cambodia, Macau (China), Mongolia, Republic of Korea and Japan. Thus, the elimination of measles in the WHO Western Pacific Region is achievable if current problems are addressed, that is, the increase and maintenance of a high level of routine and supplementary immunization.

\section{Список литературы/References}

1. Антипова А.Ю., Бичурина М.А., Лаврентьева И.Н., Тотолян Арег А. Корь в странах Африканского региона ВОЗ на этапе элиминации инфекции // Актуальные инфекции в Гвинейской Республике: эпидемиология, диагностика и иммунитет / под ред. А.Ю. Поповой. СПб.: ФБУН НИИЭМ имени Пастера, 2017. С. 264-278. [Antipova A.Yu., Bichurina M.A., Lavrentieva I.N., Totolian Areg A. Kor' v stranakh Afrikanskogo regiona VOZ na etape eliminatsii infektsii // Aktual'nye infektsii v Gvineiskoi Respublike: epidemiologiya, diagnostika i immunitet / pod red. A.Yu. Popovoi. [Measles in countries of the WHO African Region during the elimination phase. In: Actual infections in the Republic of Guinea: epidemiology, diagnosis and immunity. Ed. A.Yu. Popova]. St. Petersburg: St. Petersburg Pasteur Institute, 2017, pp. 264-278.]

2. Попова А.Ю., Бичурина М.А., Лаврентьева И.Н., Железнова Н.В., Антипова А.Ю., Щербакова С.А., Буаро М.Й., Тотолян А.А. Изучение уровня иммунитета к вирусу кори в отдельных группах населения Гвинейской Республики в рамках глобальной программы элиминации кори. Сообщение 1 // Инфекция и иммунитет. 2016. Т. 6, № 4. С. 353358. Popova A.Yu., Bichurina M.A., Lavrentyeva I.N., Zheleznova N.V., Antipova A.Yu., Shcherbakova S.A., Boiro M.Y., Totolian A.A. Measles virus immunity level study in particular population groups of the Republic of Guinea within the framework of Global measles elimination program. Report 1. Infektsiya i immunitet = Russian Journal of Infection and Immunity, 2016, vol. 6, no. 4, pp. 79-84. doi: 10.15789/2220-7619-2016-4-353-358(In Russ.)]

3. Попова А.Ю., Бичурина М.А., Лаврентьева И.Н., Железнова Н.В., Антипова А.Ю., Щербакова С.А., Буаро М.Й., Тотолян А.А. Изучение уровня иммунитета к вирусу кори в отдельных группах населения Гвинейской Республики в рамках глобальной программы элиминации кори. Сообщение 2 // Инфекция и иммунитет. 2017. Т. 7, № 1. С. 7984. [Popova A.Yu., Bichurina M.A., Lavrentyeva I.N., Zheleznova N.V., Antipova A.Yu., Shcherbakova S.A., Boiro M.Y., Totolian A.A. Measles virus immunity level study in particular population groups of the Republic of Guinea within the framework of Global measles elimination program. Report 2. Infektsiya i immunitet $=$ Russian Journal of Infection and Immunity, 2017, vol. 7 , no. 1, pp. 79-84. doi: 10.15789/2220-7619-2017-1-79-84(In Russ.)]

4. Hang L.K.N., Do L.P., Van T.T.T., Nguyen S.V., Hoang P.V.M., Pham H.T., Le T.T., Tran H.T.T., Vuong C.D., Mai T.Q.L. Viral co-infections among children with confirmed measles at hospitals in Hanoi, Vietnam, 2014. Asian Pac. J. Trop. Med., 2017, vol. 10, no. 2, pp. 171-174. 
5. Ji Y., Xu S., Zhang Y., Zhu Z., Mao N., Jiang X., Ma C., Lu P., Wang C., Liang Y., Zheng H., Liu Y., Dai D., Zheng L., Zhou J., Wang S., Zhang Z., Wu S., Nan L., Li L., Liang X., Featherstone D. A., Rota P. A., Bellini W. J., Xu W. Genetic characterization of wild-type measles viruses isolated in China, 2006-2007. Virol. J., 2010, vol. 7, pp. 105.

6. Kien V. D., Minh H.V., Giang K.B., Mai V.Q., Tuan N.T., Quam M.B. Trends in childhood measles vaccination highlight socioeconomic inequalities in Vietnam. Int. J. Public Health., 2017, vol. 62, no. 1, pp. S41-S49.

7. Kremer J.R., Nguyen G.H., Shulga S.V., Nguyen Ph.H., Nguyen U.T., Tikhonova N.T., Muller C.P. Genotyping of recent measles virus strains from Russia and Vietnam by nucleotide-specific multiplex PCR. J. Med. Virol., 2007, vol. 79, pp. 987-994.

8. Ma C., Hao L., Zhang Y., Su Q., Rodewald L., An Z., Yu W., Ma J., Wen N., Wang H., Liang X., Wang H., Yang W., Lia L., Luo H. Monitoring progress towards the elimination of measles in China: an analysis of measles surveillance data. Bulletin of the World Health Organization, vol. 92, no. 5, pp. 340-347. doi: 10.2471/BLT.13.130195

9. MacIntyre C.R., Karki S., Sheikh M., Zwar N., Heywood A.E. The role of travel in measles outbreaks in Australia - an enhanced surveillance study. Vaccine, 2016, vol. 34, no. 37, pp. 4386-4391. doi: 10.1016/j.vaccine.2016.07.023

10. Marin M., Nguyen H.Q., Langidrik J.R., Edwards R., Briand K., Papania M.J., Seward J.F., LeBaron C.W. Measles transmission and vaccine effectiveness during a large outbreak on a densely populated island: implications for vaccination policy. Clin. Infect. Dis., 2006, vol. 42, no. 3, pp. 315-319. doi: 10.1086/498902

11. NIID. Measles in Japan, 2012. Infectious Agents Surveillance Report, 2013, vol. 34, no. 2.

12. NIID. Measles in Japan (IDSC). Infectious Agents Surveillance Report, 2014, vol. 35, pp. 278-280.

13. NIID. Measles in Japan, as of March 2015. Infectious Agents Surveillance Report, 2015, vol. 36, no. 4, pp. 51-53.

14. Pham V.H., Nguyet D.P.H., Mai Kh. N. H., Truong Kh.H., Huynh L.V., Measles epidemics among children in Vietnam: genomic characterization of virus responsible for measles outbreak in Ho Chi Minh city, 2014. EBioMedicine, 2014, vol. 1, pp. $133-140$.

15. Roberts L. In Vietnam, an anatomy of a measles outbreak. Science, 2015, vol. 348, iss. 6238, pp. 962. doi: 10.1126/science.348.6238.962

16. Schluter W.W., Xiaojun W., Mendoza-Aldana J., Jee Y., Diorditsa S. Progress Toward Measles Elimination - Western Pacific Region, 2009-2012. MMWR Morb. Mortal. Wkly Rep., 2013, vol. 62, no. 22, pp. 443-447.

17. Sniadack D.H., Mendoza-Aldana J., Huyen D.T.T., Van T.T.T., Cuong N.V., Olive J.M., Toda K., Hien N.T. Epidemiology of a measles epidemic in Vietnam 2008-2010. J. Infect. Dis., 2011, vol. 204, no. 1, pp. S476-S482.

18. Soakai T.S., Sadr-Azodi N., Ozturk M., Clements C.J. Measles control in pacific island countries and territories. Ann. Virol. Res., 2016, vol. 2, no. 3, pp. 1022.

19. Tran D. Respiratory viral coinfection and clinical disease severity. J. Pediatr., 2013, vol. 89, no. 5, pp. 421-423.

20. WHO. Draft measles and rubella elimination in the Western Pacific: regional strategy and plan of action. URL: http://www.wpro. who.int/about/regional committee/68/documents/wpr rc68 4 annex measles rubella elimination.pdf

21. WHO. Brunei Darussalam, Cambodia, Japan verified as achieving measles elimination. Western Pacific Region achieves progress towards measles elimination, but challenges remain. News release, 2015. URL: http://www.wpro.who.int/mediacentre/releases/2015/20150327/en

22. WHO. Expanded programme on immunization. Regional and country profiles of measles elimination. URL: http://www.wpro.who. int/immunization/documents/measles_regional_country_profile/en

23. WHO. Global measles and rubella strategic plan: 2012-2020. Geneva, Switzerland: World Health Organization, 2012. URL: http:// www.who.int/immunization/newsroom/Measles_Rubella_StrategicPlan_2012_2020.pdf

24. WHO. Global Measles and Rubella Update. April 2018. Measles. URL $\bar{L}:$ http://www.who.int/immunization/monitoring_surveillance/ burden/vpd/surveillance_type/active/Global_MR_Update_April_2018.pdf?ua=1

25. WHO. Immunization, Vaccines and Biologicals. Measles and Rubella surveillance data. URL: http://www.who.int/immunization/ monitoring_surveillance/burden/vpd/surveillance_type/active/measles_monthlydata/en

26. WHO. Manual for the laboratory diagnosis of measles and rubella virus infection. Second edition. URL: https://globalhealthlaboratories.tghn.org/site_media/media/articles/measles_procedures.pdf

27. WHO. Measles-Rubella Bulletin. 2018, vol. 12, no. 2, pp. 1-10. URL: http://www.wpro.who.int/immunization/documents/measles_ rubella bulletin/en

28. WHO. Measles and Rubella status report: progress, challenges and lessons. Meeting of the WHO Strategic Advisory Group of Experts. 7 November, 2012. URL: http://www.who.int/immunization/sage/meetings/2012/november/2_Measles_Figueroa.pdf

29. WHO. Regional health leaders target elimination of: measles and rubella; HIV, hepatitis B and syphilis in babies. News release. URL: http://www.wpro.who.int/mediacentre/releases/2017/20171011/en

30. WHO. Reported measles cases and incidence rates by WHO States 2013, 2014 as of 11 February 2015. URL: http://www.who.int/ immunization/monitoring_surveillance/burden/vpd/surveillance_type/active/measlesreportedcasesbycountry.pdf

31. Zhang Y. An update for the western pacific region including an update on the current outbreak in mongolia. WHO. Report on the $13^{\text {th }}$ global measles and rubella laboratory network meeting, WHO/HQ Geneva, 29 June - 1 July 2015, pp. 18-19. URL: http://www. who.int/immunization/monitoring_surveillance/burden/laboratory/13th_GMRLN_Draft_Report_final.pdf

\section{Авторы:}

Антипова А.Ю., к.б.н., старший научный сотрудник лаборатории экспериментальной вирусологии ФБУН НИИ эпидемиологии и микробиологии имени Пастера,

Санкт-Петербург, Россия;

Бичурина М.А., д.м.н., зав. лабораторией этиологии и контроля вирусных инфекций ФБУН НИИ эпидемиологии и микробиологии имени Пастера, Санкт-Петербург, Россия; Лаврентьева И.Н., д.м.н., зав. лабораторией экспериментальной вирусологии ФБУН НИИ эпидемиологии и микробиологии имени Пастера, Санкт-Петербург, Россия.

\section{Authors:}

Antipova A.Yu., PhD (Biology), Senior Researcher, Laboratory of Experimental Virology, St. Petersburg Pasteur Institute, St. Petersburg, Russian Federation;

Bichurina M.A., PhD, MD (Medicine), Head of the Laboratory of Etiology and Control of Viral Infections, St. Petersburg Pasteur Institute, St. Petersburg, Russian Federation;

Lavrentieva I.N., PhD, MD (Medicine), Head of the Laboratory of Experimental Virology, St. Petersburg Pasteur Institute, St. Petersburg, Russian Federation. 